慶應義塾大学学術情報リポジトリ

Keio Associated Repository of Academic resouces

\begin{tabular}{|c|l|}
\hline Title & $\begin{array}{l}\text { Finite element analysis of the stresses around endosseous implants in various reconstructed } \\
\text { mandibular models }\end{array}$ \\
\hline Sub Title & 再建下顎においてインプラント周辺に発生する応力に関する構造力学的解析 \\
\hline Author & 永竿, 智久(Nagasao, Tomohisa) \\
\hline Publisher & 慶應医学会 \\
\hline Publication year & 2003 \\
\hline Jtitle & 慶應医学 (Journal of the Keio Medical Society). Vol.80, No.2 (2003.6),p.37- \\
\hline JaLC DOI & \\
\hline Abstract & \\
\hline Notes & 号外 \\
\hline Genre & Journal Article \\
\hline URL & https://koara.lib.keio.ac.jp/xoonips/modules/xoonips/detail.php?koara_id=AN00069296-2003060 \\
& 2-0037 \\
\hline
\end{tabular}

慶應義塾大学学術情報リポジトリ(KOARA)に掲載されているコンテンッの著作権は、それぞれの著作者、学会または出版社/発行者に帰属し、その権利は著作権法によって 保護されています。引用にあたっては、著作権法を遵守してご利用ください。

The copyrights of content available on the KeiO Associated Repository of Academic resources (KOARA) belong to the respective authors, academic societies, or publishers/issuers, and these rights are protected by the Japanese Copyright Act. When quoting the content, please follow the Japanese copyright act. 


\title{
Finite element analysis of the stresses around endosseous implants in various reconstructed mandibular models
}

\author{
(再建下顎においてインプラント周辺に発生する応力に関する構造力学的解析)
}

\section{永 笋 智 久}

\section{内容の要旨}

腫瘍切除に伴い下顎骨が切除された場合、微小血管吻合手技を利 用した遊離腓骨や、その他の自家骨の移植により再建がなされる場 合が多い。さらに、咀㘉機能の再建にはインプラントの打ち込みと、 義歯の装着が不可欠となる。インプラント周辺部には、咀嚼にあた り大きな応力が発生し、それが過度である場合種々の合併症を若起 しうる。したがって咀嚼時にインプラント周辺に発生する応力に関 しては、歯科領域を中心に比較的早期より研究がなされてきた。し 功再建下顎に扔いて同様の検討を行った報告例はかつて認められ ない。再建下顎のインプラント治療にあたり、発生応力を計算する ことは、骨吸収・感染などの合併症を回避する上で重要な参考とな りうるであろうと考え、本研究を施行した。

実験に使用したモデルはヒト乾燥下顎骨扔よび乾燥腓骨標本のCT スライスデータを基本データとし、コンピューター上で作成した 3 次元モデルを使用した。切除範囲を 7 パターンに分類し、そのそれ ぞれが腓骨により置換されたモデルを作成した。

それぞれのモデルについて、両側の臼歯部と犬歯部にインプラン トを埋入し、上部構造にてそれらを連結した。インプラントは左右 2 本ずつ、使用されるものとし、材質はチタニウムを想定した。こ れらのモデルの右臼歯部に300Nの垂直咬合圧を加えた条件で、イン プラント周辺に発生する応力に関して計算を行った。計算には有限 要素解析ソフトウェア (ANSYS5.6) を用いた。評価は 4 本のインプ ラントのうち、比較的大きな応力の発生する負荷側の 2 本に関して 重点を置いて行った。その結果負荷側臼歯部周辺においては、全て のモデルにおいて最大ひずみ応力はインプラント孔の後外側に生じ たが、その大きさについては、負荷側が腓骨で形成されている場合 の方が、下顎骨の場合に比較してより大きな值をとる傾向が認めら れた。次に、負荷側犬歯部については、負荷側が下顎骨で形成され ているモデルにおいては最大ひずみ応力は後外側に発生したが、腓 骨上にある場合には前内側に発生し、画者の位置はまったく逆であ った。これらの結果より次の事項が考察された。

まず、インプラント周辺のひずみ応力の大きさは、骨皮質の構造 的相違に起因する骨皮質との接触面積が少なく、より大きな負荷を 分担する必要性があるほど大きな值をとりやすい。

また、下顎骨は負荷作用時に扔ける変形は比較的少ないが、腓骨 は皮質骨が薄いため“しなる”ように彎曲する傾向がある。よって、 これらの骨の上に存在するインプラントも異なった方向から圧力を 受け、最大ひずみ応力も全く別の位置に発生する。

これらのコンピューターシミュレーションの解析結果より、イン プラントを再建下顎に埋入するに当っては、理入の方向を変化させ たり、皮質骨との接触面積を增加させるなど、通常の下顎骨に対す るのとは異なる配慮が、合併症の回避のために必要であると考えら れた。

\section{論文審査の要旨}

頭䅡部悪性腫瘍切除時に下顎骨下顎骨が合併切除された場合鼻症 血管吻合手技を利用した自家骨遊離移植による骨再建が必要となる 場合が多い。その際咀緭機能の再建には、チタン製骨接合インプラ ントの埋入による義歯の装着が必要であるが、インプラント周辺の 皮質骨に大きな咬合圧が発生する。そのため症例によっては骨吸収 や骨破壊、感染などの合併症をおこす場合がある。

このような合併症を避けるためインプラント周辺のどの部位に、 どの程度の咬合圧が発生するかを知る必要がある。歯科領域に扔い ては、無歯顎においてインプラント周辺に発生する応力に関する解 析的研究が報告されているが、加齢による無歯顎症例で行われてお り、遊離骨移植による再建下顎は長管骨を移植材料とするため力学 的特性は大きく異なってくる。

実験にはと卜乾燥下顎骨および乾燥腓骨標本を用い、CT撮影によ るスライスデー夕を基本とし切除部が腓骨で置換された状態の三次 元モデルをコンピュータ上で作成した。このモデルに300Nの垂直咬 合圧を加えインプラント周囲に生ずる応力を有限要素解析ソフトウ エア（ANSY5.6）で解析した。その結果インプラント周囲のひずみ 応力は負荷側が腓骨で形成されている場合のほうが下顎骨で形成さ れた場合より大きな影響を受け、応力を受ける部位も別の位置であ ることが判明した。これは骨皮質の構造学的相違に起因するものと 思われインプラントを再建下顎に埋入するに際しては皮質骨との接 触面積を增加させ、埋入の方向を変化させるなど通常の下顎骨とは 異なる配虑があることが判明した。

審査に扔いてはまず、本研究により求められたデー夕が、臨床成 績とどの程度一致するのかについての質問があった。これに対し、 インプラント周辺に発生する応力を実際に測定した報告がそしく、 その具体的值を得ることは困難であるが、臨床上感染の発端となる ことの多い部位と、本研究で求めた最大ひずみ応力発生部位は一致 する場合が多く、その事実が実験データの正当性を間接的に裹付け ていると回答された。

次に、本研究は 1 個の骨標本より得られたCTデータのみで解析が 行われているが、複数の下顎骨標本により、多くの再建下顎モデル を作成し検討がなされることが望ましいとの意見に対し、下顎の形 状は指摘されたとおり個人差が多い。普遍的な結論を得るには多く の個体に関して解析を行うべきであり、今後形状夕イプの異なる下 顎骨を対象として研究を継続してゆくとの回答があった。さらに、 本研究では垂直方向負荷のみをかけているが、水平方向負荷に関し て考度する必要があるのではないかとの問に対し、水平方向負荷も 垂直方向負荷と同程度に重要であり、本研究の続編として報告中で あるとの回答があった。

本研究で得られたデー夕は咀嘅機能快復のため行う血管柄付き遊 離骨移植による下顎骨再建術の際の合併症軽減のために有意義であ ると評価された。
論文審査担当者 主査 形成外科学 中島 龍夫 整形外科学 戸山 芳昭 解剖学 相磯 貞和 耳鼻咽喉科学 小川郁 リハビリテーション医学 千野 直一 学力確認担当者: 北島 政樹、戸山 芳昭 審査委員長：戸山 芳昭

試問日：平成15年 2 月 26 日 